\title{
Potential Neuroprotective Effects of Adiponectin in Alzheimer's Disease
}

\author{
Roy Chun-Laam $\mathrm{Ng}^{1,2}$ and Koon-Ho Chan $1,2,3,4, *$ \\ 1 Department of Medicine, LKS Faculty of Medicine, The University of Hong Kong, Hong Kong SAR, China; \\ royclng@hku.hk \\ 2 Research Center of Heart, Brain, Hormone and Healthy Aging, LKS Faculty of Medicine, \\ The University of Hong Kong, Hong Kong SAR, China \\ 3 Hong Kong University Alzheimer's Disease Research Network, LKS Faculty of Medicine, \\ The University of Hong Kong, Hong Kong SAR, China \\ 4 Neuroimmunology and Neuroinflammation Research Laboratory, LKS Faculty of Medicine, \\ The University of Hong Kong, Hong Kong SAR, China \\ * Correspondence: koonho@hku.hk; Tel.: +852-3917-9735 \\ Academic Editor: Katalin Prokai-Tatrai \\ Received: 23 December 2016; Accepted: 28 February 2017; Published: 9 March 2017
}

\begin{abstract}
The adipocyte-secreted protein adiponectin (APN) has several protective functions in the peripheral tissues including insulin sensitizing, anti-inflammatory and anti-oxidative effects that may benefit neurodegenerative diseases such as Alzheimer's disease (AD). In addition, dysregulation of cerebral insulin sensitivities and signaling activities have been implicated in AD. Emerging insights into the mechanistic roles of adiponectin and AD highlight the potential therapeutic effects for AD through insulin signaling.
\end{abstract}

Keywords: adiponectin; Alzheimer's disease; cognitive impairments; Amyloid- $\beta$

\section{Introduction}

The central nervous system (CNS) is separated from the peripheral circulations by the blood-brain barrier (BBB), which stringently controls substance penetration in order to protect the brain from pathogenic micro-organisms and harmful toxins. The CNS receives and integrates information to coordinate the whole body's activities. Intriguingly, peripheral tissues can also produce chemokines and cytokines to regulate homeostasis and metabolism in the CNS. White adipose tissue is an endocrine tissue that secretes adipokines, which exert pleiotropic effects in different tissues. Several adipokine receptors including adiponectin, leptin, and resistin receptors are abundantly expressed in different brain regions. Dysregulation of adipokine production and/or levels is associated with neurological and neurodegenerative diseases that can notably be a result of obesity-related metabolic disorders. In this review, we will discuss the plausible mechanisms of adiponectin (APN) and its protective effects in Alzheimer's disease.

\subsection{Association between Alzheimer's Disease and Insulin Signaling}

Alzheimer's disease (AD) is the most common type of age-related neurodegenerative disorder, accounting for $70 \%$ of cases of dementia. Clinical symptoms include impaired spatial learning and memory decline, particularly the loss of episodic memory. Cognitive decline is a result of progressive neuronal and synaptic loss. In 1907, Alois Alzheimer described extensive accumulation of extracellular neuritic plaques and intracellular neuronal fibrillary tangles (NFTs) as two pathological changes in the brain of a dementia patient [1]. Only three decades ago, the plaque was identified as the aggregates of Amyloid- $\beta(A \beta)$ peptide and the NFTs were identified as intracellular aggregates of 
hyperphosphorylated Tau protein [2]. These two pathologies, together with microgliosis, astrocytosis, neuronal dystrophy and synaptic reduction, represent the hallmarks of $\mathrm{AD}$. In the A $\beta$ hypothesis, $A \beta$ is one of the major factors of $A D$ pathogenesis as the accumulation of $A \beta$ can induce other $A D$ pathologies [3-5].

The formation of $A \beta$ is caused by abnormal sequential cleavage of amyloid-precursor protein (APP) by the $\beta$ - and $\gamma$-secretases, and $\beta$-site APP-cleaving enzyme 1 (BACE1) is the $\beta$-secretase essential for $A \beta$ generation. Mutations in APP or presenilin 1 (PS1) and presenilin 2 (PS2), the subunits of $\gamma$-secretase, manifest as early onset familial AD (FAD), in which the levels of $A \beta$, mainly $A \beta_{40} \& A \beta_{42}$, are drastically increased [6]. The mutations may lead to either increased cleavage of APP by $\beta$-secretase or increased levels and aggregation of $A \beta$ [7]. These familial mutations strongly support the associations between $A \beta$ and AD. Nonetheless, FAD only accounts for $5 \%$ of AD cases. Aging is the major risk factor. Other risk factors included sporadic mutations (e.g., APOE $\varepsilon 4$ ), brain trauma, Down's syndrome, vascular destruction, or abnormal metabolic functions. These factors can impede $\mathrm{A} \beta$ clearance and trafficking, or enhance $\mathrm{A} \beta$ generation, and lead to aberrant cerebral lipid metabolism and immune responses [8-12]. Substantial studies are ongoing in order to elucidate how these risk factors are associated with $A \beta$ metabolism, immune responses, or cellular metabolic changes that lead to $\mathrm{AD}$ pathogenesis.

AD has also been described as "Type 3 Diabetes", since reduced insulin signaling is one of the major pathophysiological mechanisms in AD patients. Certainly, Type 2 Diabetes Mellitus (T2DM) is associated with cognitive impairments and considered as a risk factor for AD [13]. There are several proposed mechanisms that link insulin to AD: (1) high insulin level (hyperinsulinemia) in diabetic patients leads to the competition of insulin degrading enzyme (IDE) with $A \beta$ and thereby reduces the clearance of $A \beta$ in the brain; (2) $A \beta$ oligomers can bind to insulin receptors and block the insulin signaling pathways; (3) A $\beta$ oligomers binding may downregulate insulin receptors via insulin receptor internalization; and (4) in obese or T2DM subjects who are characterized by increased peripheral levels of TNF $\alpha, T N F \alpha$ can cross the blood-brain barrier, which results in cerebral insulin resistance due to JNK activation. Nonetheless, these hypotheses converge in the findings that deregulated insulin signaling or insulin resistance in the brain activates Glycogen Synthase Kinase 3 (GSK3), which enhances A $\beta$ production and Tau phosphorylation. Till now, accumulated evidence including human clinical and animal model studies suggests that $\mathrm{AD}$ is a degenerative metabolic disorder associated with impaired cerebral insulin signaling [14].

Dysregulated Insulin Signaling in Clinical and Animal Studies

In 1994, Razay G. found that AD patients had peripheral hyperinsulinemia, insulin resistance and were overweight, describing the possible association between insulin signaling and AD [15]. Since then, different reports have highlighted that $\mathrm{AD}$ patients may have reduced insulin signaling activities in the brain. Though AD patients were found with peripheral hyperinsulinemia, AD patients have reduced levels of insulin in the cerebrospinal fluid (CSF), indicating that insulin signaling activities may be below the normal threshold in the brain [16]. This was proven by elevated levels of phosphorylated insulin receptor substrate 1 (pIRS-1) with phosphorylation at serine 616 and serine 636 residues and reduced pAkt level in the post mortem brain [14,17]. Lower levels of insulin receptor (IR) and insulin receptor substrate $1 / 2$ (IRS1/2) were also found in the AD brain [18,19]. These lines of evidence support the increase of activated GSK3 $\beta$ levels found in AD patients [20]. AD patients have reduced CSF insulin levels that inversely correlated with $A \beta_{42}$ levels. Late middle-aged subjects who had peripheral insulin resistance displayed reduction in cerebral glucose uptake, increased $A \beta_{42}$ and pTau levels in CSF [21,22]. These indicated that insulin resistance and downregulated insulin signaling activities are associated with $\mathrm{AD}$ pathologies in patients.

The correlation between downregulated insulin signaling and AD pathology was further established in animal studies. Insulin deficiency induced by streptozotocin (STZ) in transgenic AD mice accelerated $\beta$-amyloidosis through post-translational upregulation of BACE [22]. Peripheral 
administration of STZ in mice reduced cerebral pAkt and pGSK3 $\beta^{\text {Ser9 }}$ levels, and exacerbated Tau pathology, synaptic proteins reduction and memory deficits. However, STZ-treated Tau knockout mice had reduced phenotypes, indicating that insulin deficiency and reduced insulin signaling is a cause of Tau-mediated cognitive impairments [23].

\subsection{Enhancing Insulin Signaling as a Treatment for $A D$}

Hence, restoring cerebral insulin levels and its signaling activities has become a therapeutic target for AD treatment. It is hypothesized that increasing CNS insulin levels can improve memory functions and reduce $\mathrm{AD}$ phenotypes. Intranasal administration of insulin has been proposed since insulin can be degraded by digestive enzymes and therefore cannot be orally administered. This approach has been studied and has shown promising results in both animal and AD patient models [24-29]. Unfortunately, no significant change in the CSF A $\beta$ and Tau levels were detected in AD patients after intranasal insulin treatment. Notably, there is a theoretical concern that chronic high insulin levels with prolonged intranasal insulin treatment may induce cerebral insulin resistance. This is highly possible since excessive exposure to insulin in vivo and in vitro can induce insulin resistance models with decreased pAkt and pGSK3 $\beta^{\operatorname{Ser} 9}$ levels.

\section{Adiponectin}

Adiponectin is an adipocyte-derived hormone that was discovered in 1995 from 3T3-L1 adipocytes [30]. It was thought to be exclusively secreted by adipose tissue until it was found to be also expressed in hepatocytes, myocytes, osteoblasts and epithelial cells. This adipokine is secreted to the circulation and functions as an endocrine hormone to regulate glucose and lipid metabolism [31].

APN has a molecular weight of about $30 \mathrm{kDa}$ containing 244 amino acids (247 amino acids for mouse ortholog). It consists of four domains, including a signaling peptide region, a species-specific variable with cysteine residue for oligomerization, a collagenous domain comprising 22 Gly-X-Y repeats that enhances the triple helix formation in its protein structure, and a globular domain which facilitates the binding with its receptors. The full length APN protein shares structural similarities with tumor necrosis factor- $\alpha(\mathrm{TNF} \alpha)$, complement factor- $1(\mathrm{C} 1 \mathrm{q})$, collagens VIII and X. The trimeric APN is the basic form in circulation that is stabilized by hydrophobic interactions between the globular domains. Trimeric adiponectin can further undergo post-translational modification to form hexamers and high molecular weight (HMW) multimers by non-covalent disulphide bonds between the cysteine $\mathrm{Cys}^{36}$ residues (Cys ${ }^{39}$ in mouse) [32-34]. A globular fraction, globular adiponectin (gAPN) is also found in circulation post-translationally cleaved from the full length APN monomer [35]. All of these fractions account for about $0.01 \%$ of the total protein in human serum ( $0.05 \%$ in rodent). However, the trimeric and globular levels are comparatively low in plasma whereas the hexameric and HMW APN are the major forms in circulation. The physiological levels of adiponectin are generally higher in females and decrease with age in both sexes [36]. Moreover, the levels of circulating APN are also affected by various conditions including hormonal and nutritional factors, the levels of circulating cytokines, disease states, chronic inflammation and exercise [37,38]. It is well known that there is an inverse association between circulating APN levels and obesity/insulin resistance as well as T2DM $[39,40]$.

\subsection{Adiponectin Receptors and Adiponectin Signaling}

Adiponectin can act on various tissues to provide insulin sensitizing, anti-inflammatory, anti-oxidative and anti-atherogenic effects. Two main receptors modulate APN signaling transduction; adiponectin receptor 1 (AdipoR1) and adiponectin receptor 2 (AdipoR2). These two receptors are differentially expressed in the liver, skeletal muscle, cardiac muscle, osteoblasts, adipose tissues, pancreas, leukocytes, endothelial cells, and the brain. Adaptor protein, phosphotyrosine interacting with PH domain and leucine zipper 1 (APPL1) binds to both AdipoRs and serves as a link between receptors and the downstream signaling molecules. The signaling molecules activated by adiponectin 
include AMPK, p38MAPK, ERK1/2-MAPK and PPAR $\alpha$. Among these, AMPK acts as the main downstream effector of adiponectin. Numerous evidence has shown that Adiponectin-AdipoR1-AMPK activation provides various beneficial metabolic and protective effects to different tissues. AMPK mediates APN signaling to enhance insulin sensitivity through mTOR-p70S6K inhibition and serine phosphorylation of IRS-1 [41] in skeletal muscle. APN also activates AMPK, which phosphorylates acetyl-CoA carboxylase (ACC), enhances fatty acid oxidation, glucose uptake and utilization in liver, muscle [42] and adipocytes [43]. Signaling via AdipoR1 increases IRS-1 expression and activates APPL1 which promotes IRS-1/2 binding to insulin receptors [44,45]. Besides improving insulin sensitivity and glucose metabolism, APN exerts anti-inflammatory activities by counteracting the actions of inflammatory cytokines. APN can suppress TNF $\alpha$ production through the inhibition of p38MAPK and $\mathrm{TNF} \alpha$-mediated inflammatory signaling from macrophages [46-48]. It also blocks the action of TNF $\alpha$ and IL1 $\beta$ in lung epithelial tissues [49]. Last but not least, APN provides protection from oxidative stress-mediated cytotoxicity by reducing the production of reactive oxidative stress through AMPK signaling [50-52].

\subsection{Adiponectin in the Brain}

In contrast to substantial information about the roles of APN in peripheral tissues, the effect of adiponectin in the CNS is largely unknown. APN is not expressed in the brain. However, intracerebroventricular (ICV) injection of APN stimulated the paraventricular nucleus, a region involved in energy hemostasis. ICV injection of APN decreased weight gain in mice by increasing energy expenditure [53]. It was first suggested that APN was unable to cross the blood-brain barrier and could not be detected in the CSF [54,55], until several reports showed that APN was detectable in the CSF of patients with unspecified neurological disorders and in healthy subjects after IV injection of APN [56-59]. This may be due to the sensitivity of the analytical methods, as the CSF APN level is 1000-fold lower than the plasma level [56]. The distribution of APN oligomers in the CSF differs from that of the serum. Above $80 \%$ of the CSF APN is trimeric and the remaining $20 \%$ is constituted by other low molecular weight (LMW) adiponectin isoforms (e.g., hexamers) [57]. Similar experiments have been performed in mice and have shown that APN levels in the mouse CSF is 100-fold lower than plasma levels $[53,60]$. AdipoR1 and AdipoR2 are also highly expressed in different brain regions, including the hypothalamus, cortex, hippocampus, pituitary glands, and area postrema [61].

The physiological functions of APN in the CNS were first identified in association with food intake and body weight control [53]. It acts on the hypothalamus and activates AdipoR1-AMPK signaling to regulate food intakes, energy expenditure, and lipid and glucose metabolism during fasting $[62,63]$. Central administration of APN improves hypothalamic insulin signaling activities in diabetic rats and improves glucose homeostasis [64]. APN regulates neurogenesis and proliferation of hippocampal neural stem cells $[60,65]$. In addition, APN deficiency reduces dendritic growth and spine density in the hippocampal dentate gyrus in which the neural progenitor cells proliferation and differentiation is suppressed [66]. Besides neuroanatomical values, APN is also important in psychological functions. APN knockout (APN-KO) mice exhibit depressive-like behavior [67]. Physical activities and environmental enrichment can increase cerebral APN levels, which exert anti-depressive effects, increase hippocampal neurogenesis, and reduce neuroinflammation in mice $[60,68,69]$. Loss of APN in mice also exacerbates the severity of encephalomyelitis by activating lymphocytes in the mouse model of multiple sclerosis [70]. APN has anti-inflammatory and anti-atherosclerotic effects in the periphery. It is suggested that it also exerts a protective effect against ischemic brain injury. Clinical reports revealed an association between decreased APN levels and ischemic stroke. Adiponectin gene polymorphisms are associated with the risk of ischemic stroke [71,72]. Expression of adiponectin in vascular endothelial cells was increased in mice after cerebral ischemia/reperfusion injury [73]. APN treatment in mice protected the integrity of the blood-brain barrier against cerebral ischemic injury by suppressing the expression of inflammatory cytokines, and it also improved neurobehavioral 
performance and focal cerebral neurogenesis [74]. In summary, APN not only controls metabolism through the hypothalamic-pituitary axis, but also exerts enormous protective effects to the CNS.

\section{Pathophysiological Roles of Adiponectin in Alzheimer's Disease}

Adiponectin has protective effects to the CNS. Studies have been conducted to investigate the roles of adiponectin in neurodegenerative disease. In 2011, Une et al. found increased CSF APN in patient with mild cognitive impairment (MCI) but not in AD patients, when compared with control subjects [75]. A year after the report by Une et al. was published, a prospective clinical study concluded the increased plasma adiponectin level is an independent risk factor for dementia and AD in women [76]. Texixeira A.L. and his colleagues found reduced serum adiponectin levels in MCI and AD patients with similar subject size [77]. More recently, Wennberg et al. found that the serum adiponectin is positively correlated to the levels of amyloid but inversely correlated to the hippocampal volume in women with $\mathrm{MCI}$ [78]. Waragi et al. revealed a reduction of CSF APN levels in AD patients correlating to an increase of CSF $A \beta_{42}$, CSF p-Tau and the presence of hippocampal atrophy. This research group also suggested that an increase of circulating adiponectin levels could be a compensatory effect against neurodegeneration [79]. In contrast to previous findings, another report showed no significant difference of adiponectin levels between a non-demented group and patients with dementia [80]. Furthermore, Yu et al. found correlations between adiponectin gene polymorphism and late onset AD [81]. Two studies reported on low adiponectin levels in T2DM patients who had reduced gray matter volume, hippocampal volume and glucose metabolism, to be consistent with Alzheimer's disease pathophysiologies $[79,82]$. Another group reported that T2DM patients with MCI had lowered serum adiponectin levels [83]. Besides human patients, Kurata et al. showed the reduction of serum APN levels in APP transgenic mice [84]. Adiponectin transport to the brain decreased with age while peripheral APN levels showed no difference between young and aged rats [85]. This indicated that the cerebral APN may be important for memory and learning. However, these clinical studies cannot provide insight regarding the causality of adiponectin to $\mathrm{AD}$. These studies only revealed associations or correlations, and showed variation among different study groups. No cause-and-effect study had been conducted until we recently reported that chronic adiponectin deficiency elicited AD-like phenotypes, pathologies and cognitive impairments with cerebral insulin resistance in aged mice [86].

In 2012, we showed that APN was neuroprotective against oxidative stress-induced cytotoxicity under $A \beta$ toxicity in vitro [87]. We hypothesized that hypoadiponectinemia may lead to $A \beta$ accumulation, which is neurotoxic and may result in neurodegeneration. Recently, we found that aged mice with chronic adiponectin deficiency had memory decline, spatial learning impairment, increased anxiety, and impaired contextual fear conditioning. Deregulated cerebral insulin signaling activities and reduced hippocampal insulin sensitivity developed during the aging of APN-KO mice. Aberrant activation of GSK3 $\beta$ was revealed by reduced $p G S K 3 \beta^{S 9}$ and increased $p G S K 3 \beta^{\mathrm{Y} 279}$ levels in aged APN-KO mice. These findings provide an explanation for the dramatic increase of phosphorylated Tau, increased $A \beta 42$ production and Thioflavin $S$ positively stained $A \beta$ deposition. Intriguingly, we detected $A \beta * 56$ in the brain of aged APN-KO mice whereas it was absent in the brain of the wild-type mice. Moreover, we found increased microgliosis, astrogliosis with increased cerebral TNF $\alpha$ and IL1 $\beta$ levels that are the common hallmarks of AD. The reduced synaptic proteins levels and increased neuronal apoptosis also indicated that chronic adiponectin deficiency was associated with neurodegeneration in aging (Figure 1). Adiponectin-treated SH-SY5Y neuroblastoma cells carrying $\mathrm{APP}_{\text {swedish }}$ mutation had reduced extracellular A $\beta 42$ peptide. SH-SY5Y neuroblastoma cells treated with high concentration of insulin displayed insulin resistance with reduced pAkt level. The insulin sensitivity of the insulin resistant SH-SY5Y was restored after treatment with exogenous trimeric adiponectin protein through the activation of AMPK. Our findings provide strong evidence that reduced adiponectin is associated with deregulated cerebral insulin signaling and AD pathogenesis in aged or T2DM subjects who have decreased CNS adiponectin levels [86]. 


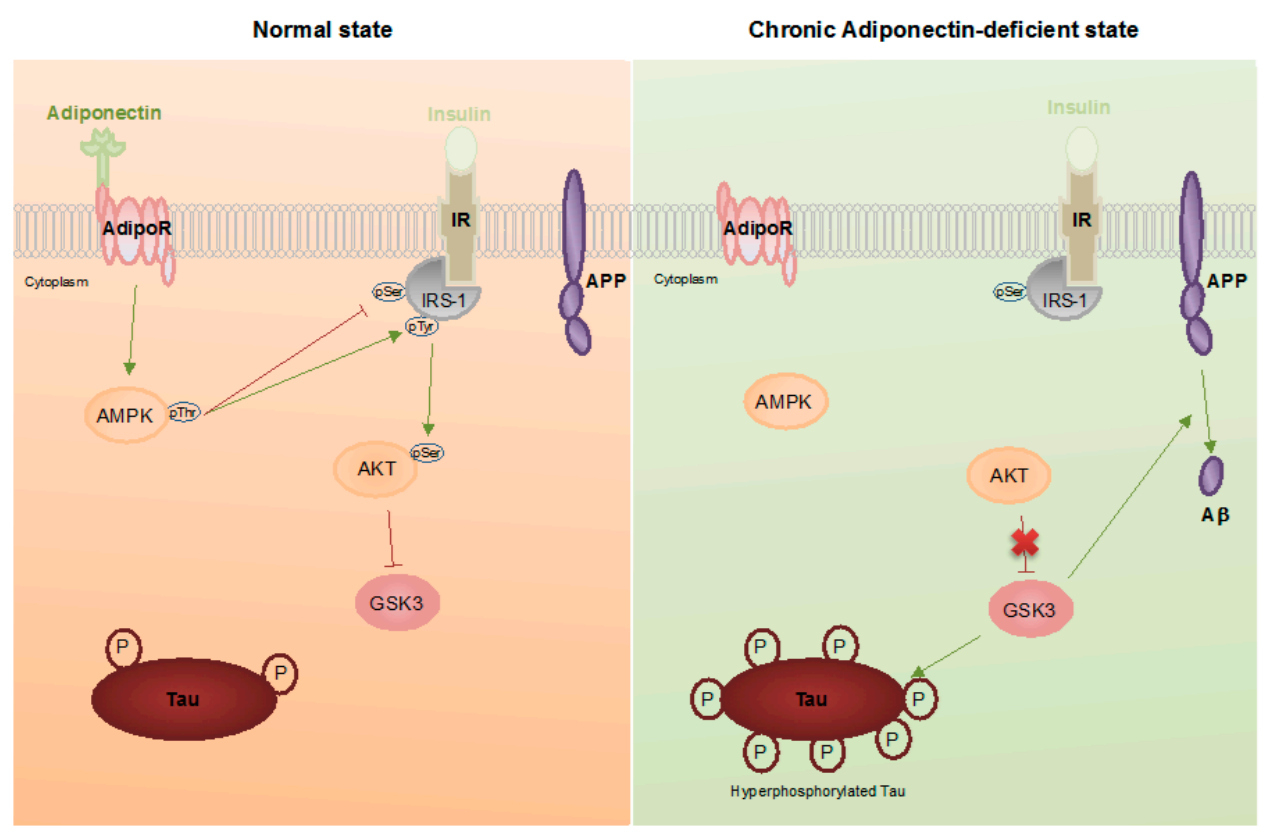

(A)

(B)

Figure 1. Pathophysiological roles of adiponectin in Alzheimer's disease (AD). Schematic outline of neuronal adiponectin signaling in the normal brain (A); and adiponectin-deficient brain (B). Under physiological conditions, adiponectin binds to its receptor and triggers phosphorylation of AMPK which inhibits IRS-1 phosphorylation at serine residues. This increases insulin-mediated IRS-1 phosphorylation at tyrosine residues and promotes downstream Akt-mediated GSK3 inhibition. Inhibition of GSK3 slows down phosphorylation of Tau and APP metabolism. In AD, chronic adiponectin deficiency leads to an increase of IRS-1 phosphorylation at serine residues (e.g., Serine 616). This causes reduced pIRS-1Tyr and results in GSK3 activation. Activated GSK3 enhances Tau phosphorylation and $\mathrm{A} \beta$ production in neurons. Arrows denote promotion, T-bars denote inhibition.

It is suggested that rodents do not develop amyloid pathologies, probably because of the longevity and low aggregating propensity of rodent $A \beta$. Mice with a specific gene knocked out or carrying mutated human APP or PS transgene have increased A $\beta$ deposition and generation. We found that the aged APN-KO mice had increased GSK3 $\beta$ activity with increased A $\beta$ production. A recent report indicates that the inhibition of GSK3 $\beta$ activity can decrease BACE1 expression, which results in reduced $A \beta$ production [88]. We also found increased formation of a specific $A \beta$ oligomer $\left(A \beta^{* 56}\right)$ in aged APN-KO mice with no dimeric or trimeric $A \beta$ being detected. $A \beta * 56$ is a specific $A \beta$ oligomer found in patients with $\mathrm{MCI}$ and transgenic $\mathrm{AD}$ mice at a young age [89]. A $\beta^{*} 56$ leads to dose-dependent cognitive decline in mice, whereas trimeric $A \beta$ does not [90]. Though the detailed mechanism of how adiponectin regulates the formation of $A \beta * 56$ remains unknown, adiponectin deficiency promotes rodent $A \beta$ production through GSK3 $\beta$-mediated activities.

In summary, it is hypothesized that the decrease of APN levels or reduction in adiponectin signaling activities can be a cause of $\mathrm{AD}$ pathogenesis and cognitive impairments. The association is highly linked to the deregulated insulin signaling activities and reduced insulin sensitivity in the brain.

\section{Therapeutic Potential of Adiponectin}

Effective treatment or medication for AD is currently limited. Donepezil is one of the four acetylcholinesterase inhibitors that are marketed drugs for the symptomatic treatment of AD. Intriguingly, the serum adiponectin levels progressively increased in AD patients who were administered with Donepezil [91]. Adiponectin has been considered as a therapeutic target to treat metabolic syndromes because of its potent protective effects to both the CNS and peripheral tissues. However, adiponectin cannot be orally administered due to its protein nature. Intravenous injection of 
recombinant adiponectin protein can by-pass the digestive system, but prolonged injection treatments are costly. The inventions of pharmacological agents or changes of lifestyle to elevate endogenous adiponectin expression or activate adiponectin signaling may pave the road for future AD treatment.

Physical exercise has long been considered to exert beneficial effects on brain functions, improve psychiatric symptoms and delay progression of neurodegenerative diseases. Increase of peripheral adiponectin levels and transport of adiponectin across the BBB were reported in rodents and human with increased physical exercise. Peroxisome proliferator-activated receptor $\gamma$ (PPAR $\gamma$ ) agonist increases adiponectin expression and exerts insulin-sensitizing effects. PPAR $\gamma$ agonist such as pioglitazone is an approved medication to T2DM patients. Repositioning of pioglitazone to treat $\mathrm{AD}$ is under investigation. AD mice fed with pioglitazone have shown cognitive improvements and suppressed microglial reactivation. However, it is known that pioglitazone crosses the BBB weakly and whether it works through adiponectin to exert neuroprotection remains uncertain (Figure 2).

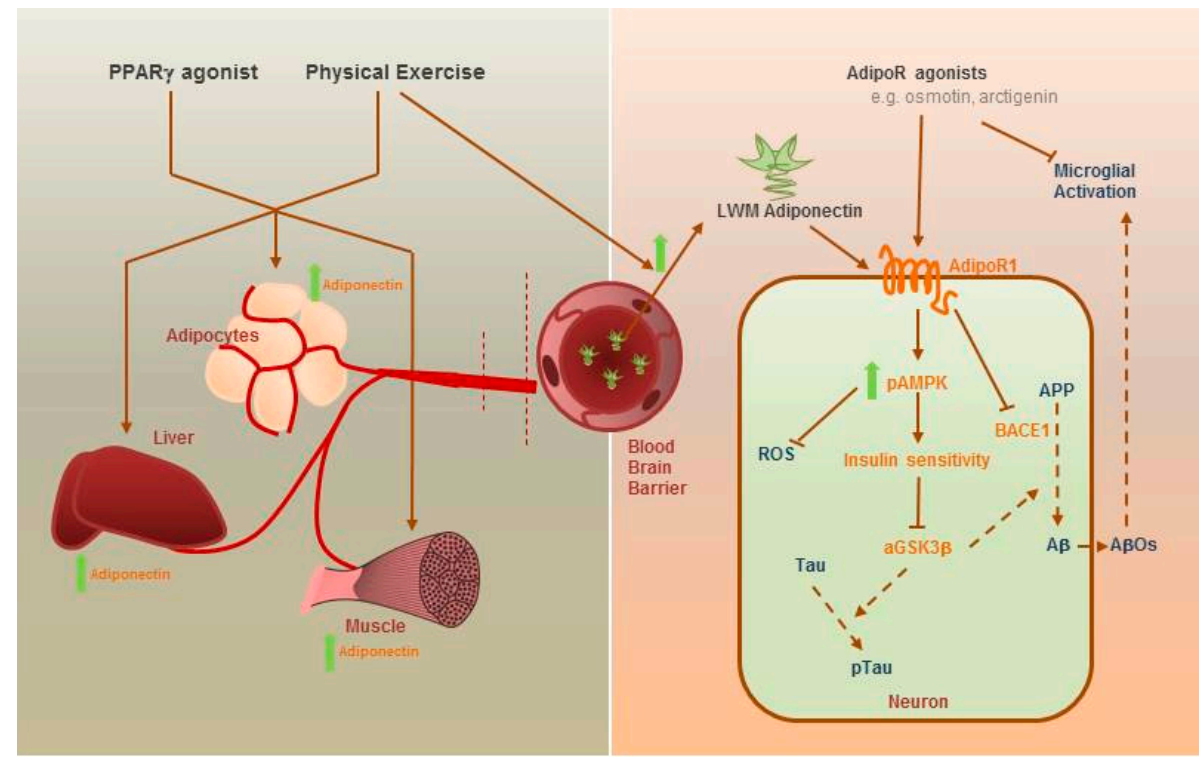

Figure 2. Strategies to increase adiponectin signaling in AD neurons. Peripherally, adiponectin expression from the liver, adipocytes and muscle can be increased by administering PPAR $\gamma$ agonist (e.g., pioglitazone) and physical exercise induction. Physical exercise can also increase the transport of low molecular weight nd trimeric adiponectin across the blood-brain barrier (BBB). Administration of adipoR agonists and LMW adiponectin acts on AdipoR1 in neurons and microglia to exert neuroprotection. Green arrow denotes increase, arrows and dash arrows denote promotion, T-bars denote inhibition.

More recently, several adiponectin receptor agonists have been discovered. In 2013, several adiponectin receptor 1 agonists were discovered including matairesinol, arctiin, arctigenin and gramine from the screening of 10,000 natural compounds [92]. Concomitantly, in the same year, arctigenin was found to improve memory functions in the AD mice model that suppressed $\mathrm{A} \beta$ production by inhibiting BACE1 activity and enhanced autophagic clearance of $A \beta$ by Akt-mTOR inhibition and AMPK activation. Last but not the least, osmotin, a plant homolog of mammalian adiponectin, was identified as a novel adipoR1 agonist which is neuroprotective against ethanol-induced apoptosis and glutamate-induced synaptic dysfunction in rat brain. It also suppresses $A \beta$-induced memory impairments, Tau phosphorylation and neurodegeneration in mouse hippocampus. Furthermore, it modulates microglia activation against LPS-induced neuroinflammation through AdipoR1-TLR4/NF-kB signaling cascade [93]. Notably, osmotin was found to improve synaptic functions and cognitive functions, and diminish $A \beta$ production and aggregation through AdipoR1-AMPK-SIRT1 pathway. 


\section{Conclusions}

It is indicated that hypoadiponectinemia in the brain may be implicated in neurodegeneration during aging. The reduced adiponectin levels in T2DM patients may be a factor which increases the risk of AD. T2DM patients or subjects with chronic adiponectin deficiency may develop cerebral insulin resistance. Decreased cerebral insulin signaling activities promotes A $\beta$ production and Tau phosphorylation, causing neuroinflammation and neurodegeneration. Regarding its neuroprotective roles including insulin sensitizing, anti-inflammatory and anti-oxidative effects, adiponectin may pave the road to prevent and treat Alzheimer's disease.

Acknowledgments: This work was supported by the Health and Medical Research Fund (HMRF) 03143856 \& 03143886. We also thank Myriam Bunting who provided technical check for the article.

Conflicts of Interest: Koon-Ho Chan has received research funding support from Merck Pharmaceutical Ltd., Novartis Pharmaceutical Ltd., Bayer HealthCare Ltd., honorarium for invited lectures from Biogen Idec and UCH Pharma Ltd., and sponsorship to attend conferences from Novartis Pharmaceutical Ltd., Bayer HealthCare Ltd., UCH Pharma Ltd. and Sanofi Genzyme. Roy Chun-Laam Ng declares no conflict of interest.

\section{Abbreviations}

\begin{tabular}{|c|c|}
\hline $\mathrm{AD}$ & Alzheimer's disease \\
\hline $\mathrm{A} \beta$ & Amyloid- $\beta$ \\
\hline AdipoR & Adiponectin receptor \\
\hline AMPK & $5^{\prime}$ adenosine monophosphate-activated protein kinase \\
\hline $\mathrm{APN}$ & Adiponectin \\
\hline APP & Amyloid precursor protein \\
\hline APPL1 & Adaptor protein, phosphotyrosine interacting with $\mathrm{PH}$ domain and leucine zipper 1 \\
\hline BACE1 & $\beta$-site APP cleaving enzyme 1 \\
\hline BBB & Blood-brain barrier \\
\hline CNS & Central nervous system \\
\hline ERK1/2 & Extracellular signal-regulated kinase1/2 \\
\hline FAD & Familial Alzheimer's disease \\
\hline GSK & Glycogen synthase kinase \\
\hline HMW & High molecular weight \\
\hline ICV & Intracerebroventricular \\
\hline IV & Intravenous \\
\hline IDE & Insulin degrading enzyme \\
\hline IL1 $\beta$ & Interleukin $1 \beta$ \\
\hline IR & Insulin receptor \\
\hline IRS-1 & Insulin receptor substrate 1 \\
\hline JNK & c-Jun N-terminal kinase \\
\hline LMW & Low molecular weight \\
\hline LPS & Lipopolysaccharide \\
\hline MAPK & Mitogen-activated protein kinases \\
\hline MCI & Mild cognitive impairment \\
\hline NFT & Neurofibrillary tangles \\
\hline mTOR & mammalian target of rapamycin \\
\hline NF-kB & Nuclear factor $\mathrm{k} B$ \\
\hline $\operatorname{PPAR} \alpha$ & Peroxisome proliferator-activated receptor $\alpha$ \\
\hline $\operatorname{PPAR} \gamma$ & Peroxisome proliferator-activated receptor $\gamma$ \\
\hline PS & Presenilin \\
\hline SIRT-1 & NAD-dependent deacetylase sirtuin-1 \\
\hline T2DM & Type 2 diabetes mellitus \\
\hline TLR4 & Toll-like receptor 4 \\
\hline $\mathrm{TNF} \alpha$ & Tumor necrosis factor $\alpha$ \\
\hline
\end{tabular}

\section{References}

1. Stelzmann, R.A.; Norman Schnitzlein, H.; Reed Murtagh, F. Uber eine eigenartige Erkrankung der Hirnrinde. Allg. Z. Psychiatr. 1907, 64, 146-148.

2. Glenner, G.G.; Wong, C.W. Alzheimer's disease: Initial report of the purification and characterization of a novel cerebrovascular amyloid protein. Biochem. Biophys. Res. Commun. 1984, 120, 885-890. [CrossRef] 
3. Hardy, J.; Selkoe, D.J. The amyloid hypothesis of Alzheimer's disease: Progress and problems on the road to therapeutics. Science 2002, 297, 353-356. [CrossRef] [PubMed]

4. Oakley, H.; Cole, S.L.; Logan, S.; Maus, E.; Shao, P.; Craft, J.; Guillozet-Bongaarts, A.; Ohno, M.; Disterhoft, J.; VanEldik, L.; et al. Intraneuronal $\beta$-amyloid aggregates, neurodegeneration, and neuron loss in transgenic mice with five familial Alzheimer's disease mutations: Potential factors in amyloid plaque formation. J. Neurosci. 2006, 26, 10129-10140. [CrossRef] [PubMed]

5. Serrano-Pozo, A.; Frosch, M.P.; Masliah, E.; Hyman, B.T. Neuropathological alterations in Alzheimer disease. Cold Spring Harb. Perspect. Med. 2011, 1, a006189. [CrossRef] [PubMed]

6. Zhang, H.; Ma, Q.; Zhang, Y.; Xu, H. Proteolytic processing of Alzheimer's $\beta$-amyloid precursor protein. J. Neurochem. 2012, 120, 9-21. [CrossRef] [PubMed]

7. Sun, X.; Bromley-Brits, K.; Song, W. Regulation of $\beta$-site APP-cleaving enzyme 1 gene expression and its role in Alzheimer's Disease. J. Neurochem. 2012, 120 (Suppl. S1), 62-70. [CrossRef] [PubMed]

8. Strittmatter, W.J.; Saunders, A.M.; Schmechel, D.; Pericak-Vance, M.; Enghild, J.; Salvesen, G.S.; Roses, A.D. Proteolytic processing of Alzheimer's $\beta$-amyloid precursor protein. Proc. Natl. Acad. Sci. USA 1993, 90, 1977-1981. [CrossRef] [PubMed]

9. Sharp, D.J.; Brooks, D.J.; Matthews, P.M.; Heckemann, R.A.; Gentleman, S.M.; Turkheimer, F.E.; Greenwood, R.J.; Leech, R.; Veronese, M.; Cole, J.; et al. Amyloid pathology and axonal injury after brain trauma. Neurology 2016, 86, 821-828.

10. Kanekiyo, T.; Xu, H.; Bu, G. ApoE and A $\beta$ in Alzheimer's disease: Accidental encounters or partners? Neuron 2014, 81, 740-754. [CrossRef] [PubMed]

11. Annus, T.; Wilson, L.R.; Hong, Y.T.; Acosta-Cabronero, J.; Fryer, T.D.; Cardenas-Blanco, A.; Smith, R.; Boros, I.; Coles, J.P.; Aigbirhio, F.I.; et al. The pattern of amyloid accumulation in the brains of adults with Down syndrome. Alzheimer's Dement. 2016, 12, 538-545. [CrossRef] [PubMed]

12. Association, A. 2013 Alzheimer's disease facts and figures. Alzheimer's Dement. 2013, 9, $208-245$.

13. García-Casares, N.; Jorge, R.E.; García-Arnés, J.A.; Acion, L.; Berthier, M.L.; Gonzalez-Alegre, P.; Nabrozidis, A.; Gutiérrez, A.; Ariza, M.J.; Rioja, J.; et al. Cognitive dysfunctions in middle-aged type 2 diabetic patients and neuroimaging correlations: A cross-sectional study. J. Alzheimer's Dis. 2014, 42, 1337-1346.

14. Talbot, K.; Wang, H.; Kazi, H.; Han, L.; Bakshi, K.P.; Stucky, A.; Fuino, R.L.; Kawaguchi, K.R.; Samoyedny, A.J.; Wilson, R.S.; et al. Demonstrated brain insulin resistance in Alzheimer's disease patients is assocaited with IGF-1 resisitance, IRS-1 dysregulation, and cogntive decline. J. Clin. Investig. 2012, 122, 1316-1338. [CrossRef] [PubMed]

15. Razay, G.; Wilcock, G.K. Hyperinsulinaemia and Alzheimer s Disease. Age Ageing 1994, 23, 396-399. [CrossRef] [PubMed]

16. Craft, S.; Peskind, E.; Schwartz, M.W.; Schellenberg, G.D.; Raskind, M.; Porte, D. Cerebrospinal fluid and plasma insulin levels in Alzheimer's disease Relationship to severity of dementia and apolipoprotein $\mathrm{E}$ genotype. Neurology 1998, 50, 164-168. [CrossRef] [PubMed]

17. Yarchoan, M.; Toledo, J.B.; Lee, E.B.; Arvanitakis, Z.; Kazi, H.; Han, L.Y.; Louneva, N.; Lee, V.M.Y.; Kim, S.F.; Trojanowski, J.Q.; et al. Abnormal serine phosphorylation of insulin receptor substrate 1 is associated with tau pathology in Alzheimer's disease and tauopathies. Acta Neuropathol. 2014, 128, 679-689. [CrossRef] [PubMed]

18. Steen, E.; Terry, B.M.; Rivera, E.J.; Cannon, J.L.; Neely, T.R.; Tavares, R.; Xu, X.J.; Wands, J.R.; dela Monte, S.M. Impaired insulin and insulin-like growth factor expression and signaling mechanisms in Alzheimer's disease-Is this type 3 diabetes? J. Alzheimer's Dis. 2005, 7, 63-80.

19. Moloney, A.M.; Griffin, R.J.; Timmons, S.; O'Connor, R.; Ravid, R.; O'Neill, C. Defects in IGF-1 receptor, insulin receptor and IRS-1/2 in Alzheimer's disease indicate possible resistance to IGF-1 and insulin signalling. Neurobiol. Aging 2010, 31, 224-243. [CrossRef] [PubMed]

20. Pei, J.-J.; Sabiha, K.; An, W.-L.; Maria, N.; Toshihisa, T.; Heiko, B.; Ichiro, T.; Masatoshi, T.; Irina, A.; Bengt, W.; et al. Role of protein kinase B in Alzheimer's neurofibrillary pathology. Acta Neuropathol. 2003, 105, 381-392. [PubMed]

21. Hoscheidt, S.M.; Starks, E.J.; Oh, J.M.; Zetterberg, H.; Blennow, K.; Krause, R.A.; Gleason, C.E.; Puglielli, L.; Atwood, C.S.; Carlsson, C.M.; et al. Insulin Resistance is Associated with Increased Levels of Cerebrospinal Fluid Biomarkers of Alzheimer's Disease and Reduced Memory Function in At-Risk Healthy Middle-Aged Adults. J. Alzheimer's Dis. 2016, 52, 1374-1483. [CrossRef] [PubMed] 
22. Anderson, N.J.; King, M.R.; Delbruck, L.; Jolivalt, C.G. Role of insulin signaling impairment, adiponectin and dyslipidemia in peripheral and central neuropathy in mice. Dis. Model. Mech. 2014, 7, 625-633. [CrossRef] [PubMed]

23. Abbondante, S.; Baglietto-Vargas, D.; Rodriguez-Ortiz, C.J.; Estrada-Hernandez, T.; Medeiros, R.; LaFerla, F.M. Genetic ablation of tau mitigates cognitive impairment induced by type 1 diabetes. Am. J. Pathol. 2014, 184, 819-826. [CrossRef] [PubMed]

24. Chen, Y.; Zhao, Y.; Dai, C.-L.; Liang, Z.; Run, X.; Iqbal, K.; Liu, F.; Gong, C.X. Intranasal insulin restores insulin signaling, increases synaptic proteins, and reduces $\mathrm{A} \beta$ level and microglia activation in the brains of 3xTg-AD mice. Exp. Neurol. 2014, 261, 610-619. [CrossRef] [PubMed]

25. Vandal, M.; White, P.J.; Tremblay, C.; St-Amour, I.; Chevrier, G.; Emond, V.; Lefrancois, D.; Virgili, J.; Planel, E.; Giguere, Y.; et al. Insulin reverses the high-fat diet-induced increase in brain A $\beta$ and improves memory in an animal model of Alzheimer disease. Diabetes 2014, 63, 4291-4301. [CrossRef] [PubMed]

26. Rajasekar, N.; Nath, C.; Hanif, K.; Shukla, R. Intranasal Insulin Administration Ameliorates Streptozotocin (ICV)-Induced Insulin Receptor Dysfunction, Neuroinflammation, Amyloidogenesis, and Memory Impairment in Rats. Mol. Neurobiol. 2016. [CrossRef] [PubMed]

27. Park, C.R.; Seeley, R.J.; Craft, S.; Woods, S.C. Intracerebroventricular insulin enhances memory in a passive-avoidance task. Physiol. Behav. 2000, 68, 509-514. [CrossRef]

28. Reger, M.A.; Watson, G.S.; Green, P.S.; Wilkinson, C.W.; Baker, L.D.; Cholerton, B.; Fishel, M.A.; Plymate, S.R.; Breitner, J.C.; DeGroodt, W.; et al. Intranasal insulin improves cognition and modulates $\beta$-amyloid in early AD. Neurology 2008, 70, 440-448. [CrossRef] [PubMed]

29. Watson, G.S.; Claxton, A.; Arbuckle, M.; Leverenz, J.; Cross, D.; Gerton, B. Intranasal Insulin Therapy for Alzheimer Disease and Amnestic Mild Cognitive Impairment. Arch. Neurol. 2012, 69, 29-38.

30. Scherer, P.E.; Williams, S.; Fogliano, M.; Baldini, G.; Lodish, H.F. A novel serum protein similar to C1q, produced exclusively in adipocytes. J. Biol. Chem. 1995, 270, 26746-26749. [CrossRef] [PubMed]

31. Combs, T.P.; Berg, A.H.; Obici, S.; Scherer, P.E.; Rossetti, L. Endogenous glucose production is inhibited by the adipose-derived protein Acrp30. J. Clin. Investig. 2001, 108, 1875-1881. [CrossRef] [PubMed]

32. Waki, H.; Yamauchi, T.; Kamon, J.; Ito, Y.; Uchida, S.; Kita, S.; Hara, K.; Hada, Y.; Vasseur, F.; Froguel, P.; et al. Impaired multimerization of human adiponectin mutants associated with diabetes. Molecular structure and multimer formation of adiponectin. J. Biol. Chem. 2003, 278, 40352-40363. [CrossRef] [PubMed]

33. Tsao, T.S.; Murrey, H.E.; Hug, C.; Lee, D.H.; Lodish, H.F. Oligomerization state-dependent activation of NF- $\mathrm{B}$ signaling pathway by adipocyte complement-related protein of $30 \mathrm{kDa}$ (Acrp30). J. Biol. Chem. 2002, 277, 29359-29362. [CrossRef] [PubMed]

34. Tsao, T.S.; Tomas, E.; Murrey, H.E.; Hug, C.; Lee, D.H.; Ruderman, N.B.; Heuser, J.E.; Lodish, H.F. Role of Disulfide Bonds in Acrp30/Adiponectin Structure and Signaling Specificity: Different oligomers activate different signal transduction pathways. J. Biol. Chem. 2003, 278, 50810-50817. [CrossRef] [PubMed]

35. Fruebis, J.; Tsao, T.-S.; Javorschi, S.; Ebbets-Reed, D.; Erickson, M.R.S.; Yen, F.T.; Bihain, B.E.; Lodish, H.F. Proteolytic cleavage product of 30-kDa adipocyte complement-related protein increases fatty acid oxidation in muscle and causes weight loss in mice. Proc. Natl. Acad. Sci. USA 2001, 98, 2005-2010. [CrossRef] [PubMed]

36. Yukio, A.; Shinji, K.; Noriyuki, O.; Masahiko, T.; Kazuhisa, M.; Jun-ichiro, M.; Kikuko, H.; Lichiro, S.; Tadashi, N.; Koji, M.; et al. Paradoxical Decrease of an Adipose-Specific Protein, Adiponectin, in Obesity. Biochem. Biophys. Res. Commun. 1999, 257, 79-83.

37. Thundyil, J.; Pavlovski, D.; Sobey, C.G.; Arumugam, T.V. Adiponectin receptor signalling in the brain. Br. J. Pharm. 2012, 165, 313-327. [CrossRef] [PubMed]

38. Protein, A.A.; Yang, W.; Lee, W.; Funahashi, T.; Tanaka, S.; Matsuzawa, Y.; Chao, C.; Chen, C.; Tai, T.; Chuang, L. Weight Reduction Increases Plasma Levels of an adipose-derived anti-inflammatory protein, adiponectin. J. Clin. Endocrinol. Metab. 2001, 86, 3815-3819.

39. Hotta, K.; Funahashi, T.; Bodkin, N.L.; Ortmeyer, H.K.; Arita, Y.; Hansen, B.C.; Matsuzawa, Y. Circulating concentrations of the adipocyte protein adponectin are decreased in parallel with reduced insulin sensitivity during the progression to type 2 diabetes in Rhesys Monkeys. Diabetes 2001, 50, 1126-1133. [CrossRef] [PubMed]

40. Kondo, H.; Shimomura, L.; Matsukawa, Y.; Kumada, M.; Takahashi, M.; Matsuda, M.; Ouchi, N.; Kihara, S.; Kawamoto, T.; Sumitsuji, S.; et al. Association of adiponectin mutation with type 2 diabetes: A candidate gene for the insulin resistance syndrome. Diabetes 2002, 51, 2325-2328. [CrossRef] [PubMed] 
41. Wang, C.; Mao, X.; Wang, L.; Liu, M.; Wetzel, M.D.; Guan, K.L.; Dong, L.Q.; Liu, F. Adiponectin sensitizes insulin signaling by reducing p70 S6 kinase-mediated serine phosphorylation of IRS-1. J. Biol. Chem. 2007, 282, 7991-7996. [CrossRef] [PubMed]

42. Yamauchi, T.; Kamon, J.; Minokoshi, Y.; Ito, Y.; Waki, H.; Uchida, S.; Yamashita, S.; Noda, M.; Kita, S.; Ueki, K.; et al. Adiponectin stimulates glucose utilization and fatty-acid oxidation by activating AMP-activated protein kinase. Nat. Med. 2002, 8, 1288-1295. [CrossRef] [PubMed]

43. Wu, X.; Motoshima, H.; Mahadev, K.; Stalker, T.J.; Scalia, R.; Goldstein, B.J. Involvement of AMP-activated protein kinase in glucose uptake stimulated by the globular domain of adiponectin in primary rat adipocytes. Diabetes 2003, 52, 1355-1363. [CrossRef] [PubMed]

44. Ryu, J.; Galan, A.K.; Xin, X.; Dong, F.; Abdul-Ghani, M.A.; Zhou, L.; Wang, C.; Li, C.; Holmes, B.M.; Sloane, L.B.; et al. APPL1 potentiates insulin sensitivity by facilitating the binding of IRS1/2 to the insulin receptor. Cell Rep. 2014, 7, 1227-1238. [CrossRef] [PubMed]

45. 88Patel, S.A.; Hoehn, K.L.; Lawrence, R.T.; Sawbridge, L.; Talbot, N.A.; Tomsig, J.L.; Turner, N.; Cooney, G.J.; Whitehead, J.P.; Kraegen, E.W.; et al. Overexpression of the adiponectin receptor AdipoR1 in rat skeletal muscle amplifies local insulin sensitivity. Endocrinology 2012, 153, 5231-5246.

46. Mandal, P.; Pratt, B.T.; Barnes, M.; McMullen, M.R.; Nagy, L.E. Molecular mechanism for adiponectin-dependent $\mathrm{m} 2$ macrophage polarization link between the metabolic and innate immune activity of full-length adiponectin. J. Biol. Chem. 2011, 286, 13460-13469. [CrossRef] [PubMed]

47. Folco, E.J.; Rocha, V.Z.; López-Ilasaca, M.; Libby, P. Adiponectin inhibits pro-inflammatory signaling in human macrophages independent of interleukin-10. J. Biol. Chem. 2009, 284, 25569-25575. [CrossRef] [PubMed]

48. Huang, H.; Park, P.H.; McMullen, M.R.; Nagy, L.E. Mechanisms for the anti-inflammatory effects of adiponectin in macrophages. J. Gastroenterol. Hepatol. 2008, 23 (Suppl. S1), S50-S53. [CrossRef] [PubMed]

49. Nigro, E.; Scudiero, O.; Sarnataro, D.; Mazzarella, G.; Sofia, M.; Bianco, A.; Daniele, A. Adiponectin affects lung epithelial A549 cell viability counteracting TNFa and IL-1 $\beta$ toxicity through AdipoR1. Int J. Biochem. Cell Biol. 2013, 45, 1145-1153. [CrossRef] [PubMed]

50. Wan, Z.; Mah, D.; Simtchouk, S.; Klegeris, A.; Little, J.P. Globular adiponectin induces a pro-inflammatory response in human astrocytic cells. Biochem. Biophys. Res. Commun. 2014, 446, 37-42. [CrossRef] [PubMed]

51. Shrestha, A.; Park, P.H. Globular adiponectin attenuates LPS-induced reactive oxygen species production in HepG2 cells via FoxO3A and HO-1 signaling. Life Sci. 2016, 148, 71-79. [CrossRef] [PubMed]

52. Park, M.; Youn, B.; Zheng, X.L.; Wu, D.; Xu, A.; Sweeney, G. Globular adiponectin, acting via AdipoR1/APPL1, protects H9c2 cells from hypoxia/reoxygenation-induced apoptosis. PLoS ONE 2011, 6, e19143. [CrossRef] [PubMed]

53. Qi, Y.; Takahashi, N.; Hileman, S.M.; Patel, H.R.; Berg, A.H.; Pajvani, U.B.; Scherer, P.E.; Ahima, R.S. Adiponectin acts in the brain to decrease body weight. Nat. Med. 2004, 10, 524-529. [CrossRef] [PubMed]

54. Spranger, J.; Verma, S.; Göhring, I.; Bobbert, T.; Seifert, J.; Sindler, A.L.; Pfeiffer, A.; Hileman, S.M.; Tschöp, M.; Banks, W.A. Adiponectin Does Not Cross the Blood-Brain Barrier but Modifies Cytokine Expression of Brain Endothelial Cells. Diabetes 2005, 55, 141-147. [CrossRef]

55. Pan, W.; Tu, H.; Kastin, A.J. Differential BBB interactions of three ingestive peptides: Obestatin, ghrelin, and adiponectin. Peptides 2006, 27, 911-916. [CrossRef] [PubMed]

56. Neumeier, M.; Weigert, J.; Buettner, R.; Wanninger, J.; Schäffler, A.; Mü, A.M.; Killian, S.; Sauerbruch, S.; Schlachetzki, F.; Steinbrecher, A.; et al. Detection of adiponectin in cerebrospinal fluid in humans. Am. J. Physiol. Endocrinol. Metab. 2007, 293, E965-E969. [CrossRef] [PubMed]

57. Kusminski, C.M.; McTernan, P.G.; Schraw, T.; Kos, K.; O’Hare, J.P.; Ahima, R.; Kumar, S.; Scherer, P.E. Adiponectin complexes in human cerebrospinal fluid: Distinct complex distribution from serum. Diabetologia 2007, 50, 634-642. [CrossRef] [PubMed]

58. Kos, K.; Harte, A.L.; DaSilva, N.F.; Tonchev, A.; Chaldakov, G.; James, S.; Snead, D.R.; Hoggart, B.; O’Hare, J.P.; McTernan, P.G.; et al. Adiponectin and resistin in human cerebrospinal fluid and expression of adiponectin receptors in the human hypothalamus. J. Clin. Endocrinol. Metab. 2007, 92, 1129-1136. [CrossRef] [PubMed]

59. Ebinuma, H.; Yamauchi, T.; Hada, Y.; Hara, K. Improved ELISA for Selective Measurement of Adiponectin Multimers and Identification of Adiponectin in Human Cerebrospinal Fluid. Clin. Chem. 2007, 53, 1541-1548. [CrossRef] [PubMed] 
60. Yau, S.-Y.; Li, A.; Hoo, R.L.C.; Ching, Y.P.; Christie, B.R.; Lee, T.M.C.; Xu, A.; So, K.F. Physical exercise-induced hippocampal neurogenesis and antidepressant effects are mediated by the adipocyte hormone adiponectin. Proc. Natl. Acad. Sci. USA 2014, 111, 15810-15815. [CrossRef] [PubMed]

61. Fry, M.; Smith, P.M.; Hoyda, T.D.; Duncan, M.; Ahima, R.S.; Sharkey, K.A.; Ferguson, A.V. Area postrema neurons are modulated by the adipocyte hormone adiponectin. J. Neurosci. 2006, 26, 9695-9702. [CrossRef] [PubMed]

62. Kubota, N.; Yano, W.; Kubota, T.; Yamauchi, T.; Itoh, S.; Kumagai, H.; Kozono, H.; Takamoto, I.; Okamoto, S.; Shiuchi, T.; et al. Adiponectin Stimulates AMP-Activated Protein Kinase in the Hypothalamus and Increases Food Intake. Cell Metab. 2007, 6, 55-68. [CrossRef] [PubMed]

63. Wen, J.P.; Liu, C.E.; Hu, Y.T.; Chen, G.; Lin, L.X. Globular adiponectin regulates energy homeostasis through AMP-activated protein kinase-acetyl-CoA carboxylase (AMPK/ACC) pathway in the hypothalamus. Mol. Cell. Biochem. 2010, 344, 109-115. [CrossRef] [PubMed]

64. Park, S.; Kim, D.S.; Kwon, D.Y.; Yang, H.J. Long-term central infusion of adiponectin improves energy and glucose homeostasis by decreasing fat storage and suppressing hepatic gluconeogenesis without changing food intake. J. Neuroendocrinol. 2011, 23, 687-698. [CrossRef] [PubMed]

65. Zhang, D.; Guo, M.; Zhang, W. LUX:Adiponectin stimulates proliferation of adult hippocampal neural stem/progenitor cells through activation of p38 mitogen-activated protein kinase (p38MAPK)/glycogen synthase kinase $3 \beta$ (GSK-3 $\beta$ )/ $\beta$-catenin signaling cascade. J. Biol. Chem. 2011, 12, 44913-44920. [CrossRef] [PubMed]

66. Zhang, D.; Wang, X.; Lu, X.Y. Adiponectin exerts neurotrophic effects on dendritic arborization, spinogenesis, and neurogenesis of the dentate gyrus of male mice. Endocrinology 2016, 157, 2853-2869. [CrossRef] [PubMed]

67. Liu, J.; Guo, M.; Zhang, D.; Cheng, S.Y.; Liu, M.; Ding, J.; Scherer, P.E.; Liu, F.; Lu, X.Y. Adiponectin is critical in determining susceptibility to depressive behaviors and has antidepressant-like activity. Proc. Natl. Acad. Sci. USA 2012, 109, 12248-12253. [CrossRef] [PubMed]

68. Chabry, J.; Nicolas, S.; Cazareth, J.; Murris, E.; Guyon, A.; Glaichenhaus, N.; Heurteaux, C.; Petit-Paitel, A. Enriched environment decreases microglia and brain macrophages inflammatory phenotypes through adiponectin-dependent mechanisms: Relevance to depressive-like behavior. Brain Behav. Immun. 2015, 50, 275-287. [CrossRef] [PubMed]

69. Nicolas, S.; Veyssière, J.; Gandin, C.; Zsürger, N.; Pietri, M.; Heurteaux, C.; Glaichenhaus, N.; Petit-Paitel, A.; Chabry, J. Neurogenesis-independent antidepressant-like effects of enriched environment is dependent on adiponectin. Psychoneuroendocrinology 2015, 57, 72-83. [CrossRef] [PubMed]

70. Mikesell, R.; Ryu, J.; Hsieh, C.; Cremasco, V. Lack of adiponectin leads to increased lymphocyte activation and worse severity of a mouse model of multiple sclerosis. Eur. J. Immunol. 2013, 43, 2089-2100.

71. Shen, D.; Xing, S.; Chen, C. Adiponectin gene polymorphisms contributes to ischemic stroke risk: A meta-analysis. J. Renin Angiotensin Aldosterone Syst. 2015, 16, 178-184. [CrossRef] [PubMed]

72. Liu, F.; He, Z.; Deng, S.; Zhang, H.; Li, N.; Xu, J. Association of adiponectin gene polymorphisms with the risk of ischemic stroke in a Chinese Han population. Mol. Biol. Rep. 2011, 38, 1983-1988. [CrossRef] [PubMed]

73. Shen, L.; Miao, J.; Zhao, Y.; Zhao, Y.; Liang, W. Expression of brain adiponectin in a murine model of transient cerebral ischemia. Int. J. Clin. Exp. Med. 2014, 7, 4590-4596. [PubMed]

74. Miao, J.; Shen, L.H.; Tang, Y.H.; Wang, Y.T.; Tao, M.X.; Jin, K.L.; Zhao, Y.J.; Yang, G.Y. Overexpression of adiponectin improves neurobehavioral outcomes after focal cerebral ischemia in aged mice. CNS Neurosci. Ther. 2013, 19, 969-977. [CrossRef] [PubMed]

75. Une, K.; Takei, Y.A.; Tomita, N.; Asamura, T.; Ohrui, T.; Furukawa, K.; Arai, H. Adiponectin in plasma and cerebrospinal fluid in MCI and Alzheimer's disease. Eur. J. Neurol. 2011, 18, 1006-1009. [CrossRef] [PubMed]

76. Himbergen, T.M.V.; Alexa, S.B.; Ai, M.; Seshadri, S.; Otokozawa, S.; Au, R.; Thongtang, N.; Wolf, P.A.; Schaefer, E.J. Biomarkers for Insulin Resistance and Inflammation and the Risk for All-Cause Dementia and Alzheimer Disease Results From the Framingham Heart Study. Arch. Neurol. 2012, 69, 564-600.

77. Teixeira, A.L.; Diniz, B.S.; Campos, A.C.; Miranda, A.S.; Rocha, N.P.; Talib, L.L.; Gattaz, W.F.; Forlenza, O.V. Decreased levels of circulating adiponectin in mild cognitive impairment and alzheimer's disease. Neuromol. Med. 2013, 15, 115-121. [CrossRef] [PubMed]

78. Wennberg, A.M.V.; Gustafson, D.; Hagen, C.E.; Roberts, R.O.; Knopman, D.; Jack, C.; Petersen, R.C.; Mielke, M.M. Serum Adiponectin Levels, Neuroimaging, and Cognition in the Mayo Clinic Study of Aging. J. Alzheimer's Dis. 2016, 53, 573-581. [CrossRef] [PubMed] 
79. Waragai, M.; Adame, A.; Trinh, I.; Sekiyama, K.; Takamatsu, Y.; Une, K.; Masliah, E.; Hashimoto, M. Possible Involvement of Adiponectin, the Anti-Diabetes Molecule, in the Pathogenesis of Alzheimer's Disease. J. Alzheimer's Dis. 2016, 52, 1453-1459. [CrossRef] [PubMed]

80. Dukic, L.; Simundic, A.M.; Martinic-Popovic, I.; Kackov, S.; Diamandis, A.; Begcevic, I.; Diamandis, E.P. The role of human kallikrein 6, clusterin and adiponectin as potential blood biomarkers of dementia. Clin. Biochem. 2016, 49, 213-218. [CrossRef] [PubMed]

81. Yu, Z.; Li, W.; Hou, D.; Zhou, L.; Deng, Y.; Tian, M.; Feng, X. Relationship between Adiponectin Gene Polymorphisms and Late-Onset Alzheimer's Disease. PLoS ONE 2015, 10, e0125186. [CrossRef] [PubMed]

82. García-Casares, N.; García-Arnés, J.A.; Rioja, J.; Ariza, M.J.; Gutiérrez, A.; Alfaro, F.; Nabrozidis, A.; González-Alegre, P.; González-Santos, P. Alzheimer's like brain changes correlate with low adiponectin plasma levels in type 2 diabetic patients. J. Diabetes Complicat. 2016, 30, 281-286. [CrossRef] [PubMed]

83. Gorska-Ciebiada, M.; Saryusz-Wolska, M.; Borkowska, A.; Ciebiada, M.; Loba, J. Adiponectin, leptin and IL-1 $\beta$ in elderly diabetic patients with mild cognitive impairment. Metab. Brain Dis. 2016, 31, 257-266. [CrossRef] [PubMed]

84. Kurata, T.; Miyazaki, K.; Morimoto, N.; Kawai, H.; Ohta, Y.; Ikeda, Y.; Abe, K. Atorvastatin and pitavastatin reduce oxidative stress and improve IR/LDL-R signals in Alzheimer's disease. Neurol. Res. 2013, 35, $193-205$. [CrossRef] [PubMed]

85. Pancani, T.; Anderson, K.L.; Brewer, L.D.; Kadish, I.; DeMoll, C.; Landfield, P.W.; Blalock, E.M.; Porter, N.M.; Thibault, O. Effect of high-fat diet on metabolic indices, cognition, and neuronal physiology in aging F344 rats. Neurobiol. Aging 2013, 34, 1977-1987. [CrossRef] [PubMed]

86. Ng, R.C.L.; Cheng, O.Y.; Kwan, J.S.C.; Ho, P.W.L.; Cheng, K.K.Y.; Yeung, P.K.K.; Zhou, L.L.; Hoo, R.L.C.; Chung, S.K.; Xu, A.; et al. Chronic adiponectin deficiency leads to Alzheimer's disease-like cognitive impairments through AMPK inactivation and cerebral insulin resistance in aged mice. Mol. Neurodegener. 2016, 11, 71. [CrossRef] [PubMed]

87. Chan, K.H.; Lam, K.S.L.; Cheng, O.Y.; Kwan, J.S.C.; Ho, P.W.L.; Cheng, K.K.Y.; Chung, S.K.; Ho, J.W.M.; Guo, V.Y.; Xu, A. Adiponectin is Protective against Oxidative Stress Induced Cytotoxicity in Amyloid- $\beta$ Neurotoxicity. PLoS ONE 2012, 7, e52354. [CrossRef] [PubMed]

88. Ly, P.T.T.; Wu, Y.; Zou, H.; Wang, R.; Zhou, W.; Kinoshita, A.; Zhang, M.; Yang, Y.; Cai, F.; Woodgett, J.; et al. Inhibition of GSK3 $\beta$-mediated BACE1 expression reduces Alzheimer-associated phenotypes. J. Clin. Investig. 2013, 123, 224-235. [CrossRef] [PubMed]

89. Yang, D.S.; Stavrides, P.; Mohan, P.S.; Kaushik, S.; Kumar, A.; Ohno, M.; Schmidt, S.D.; Wesson, D.; Bandyopadhyay, U.; Jiang, Y.; et al. Reversal of autophagy dysfunction in the TgCRND8 mouse model of Alzheimer's disease ameliorates amyloid pathologies and memory deficits. Brain 2011, 134, 258-277. [CrossRef] [PubMed]

90. Reed, M.N.; Hofmeister, J.J.; Jungbauer, L.; Welzel, A.T.; Yu, C.; Sherman, M.A.; Lesné, S.; LaDu, M.J.; Walsh, D.M.; Ashe, K.H.; et al. Cognitive effects of cell-derived and synthetically derived A $\beta$ oligomers. Neurobiol. Aging 2011, 32, 1784-1794. [CrossRef] [PubMed]

91. Pákáski, M.; Fehér, Á.; Juhász, A.; Drótos, G.; Fazekas, Ö.C.; Kovács, J.; Janka, Z.; Kálmán, J. Serum adipokine levels modified by donepezil treatment in Alzheimer's disease. J. Alzheimer's Dis. 2014, 38, 371-377.

92. Sun, Y.; Zang, Z.; Zhong, L.; Wu, M.; Su, Q.; Gao, X.; Zan, W.; Lin, D.; Zhao, Y.; Zhang, Z. Identification of Adiponectin Receptor Agonist Utilizing a Fluorescence Polarization Based High Throughput Assay. PLoS ONE 2013, 8, e63354. [CrossRef] [PubMed]

93. Badshah, H.; Ali, T.; Kim, M.O. Osmotin attenuates LPS-induced neuroinflammation and memory impairments via the TLR4/NFKB signaling pathway. Sci Rep. 2016, 6, 24493. [CrossRef] [PubMed]

(c) 2017 by the authors. Licensee MDPI, Basel, Switzerland. This article is an open access article distributed under the terms and conditions of the Creative Commons Attribution (CC BY) license (http:/ / creativecommons.org/licenses/by/4.0/). 